\title{
TELAAH KRITIS PUTUSAN SIDANG ITSBAT PENETAPAN AWAL BULAN QAMARIYAH DI INDONESIA DALAM PERSPEKTIF USHUL FIKIH
}

\author{
Siti Tatmainul Qulub \\ Universitas Islam Negeri (UIN) Sunan Ampel Surabaya \\ e-mail : nungky_diamond@yahoo.com
}

\begin{abstract}
This study aims to criticize the implementation of the Itsbat Conference (a conference determining the beginning of Qamariyah month) implemented by the government through the Ministry of Religious Affairs. Among the important issues is what is the main factor causing the disagreements and how is the position of Itsbat Conference in usul figh point of view? Research carried out on the results of Itsbat Conference on Ramadhan and Syawwal in $1381 \mathrm{H}-1434 \mathrm{H} / 1962 \mathrm{AD}-2011 \mathrm{AD}$. The study concluded that the disagreements tend to occur due to the critical height of the new moon and approach in determining the new moon. According to usul fiqh, Itsbat Conference can be seen in multiple perspectives; The first, it is an obligation on the government as a representation of imam, to facilitate and support the implementation of the totality of praying; Second, it is a form of state responsibility to the people to promote unity, especially in the implementation of praying, by minimizing disagreements and conflicts. Thirdly, to realize maslahat 'ämmah, the essence of the maqāsid al-sharīah. Itsbat Conference is one example of maslahat hääjiyyah needed to complete the fasting of Ramadhan, 'Idul Fitr, and Idul Adha.
\end{abstract}

Penelitian ini bertujuan untuk mengkritisi pelaksanaan sidang itsbat penentuan awal bulan Qamariyah yang dilaksanakan oleh pemerintah melalui Kementerian Agama. Di antara isu-isu penting yang dikritisi adalah apa yang menjadi faktor utama penyebab terjadinya perbedaan pendapat dan bagaimana kedudukan sidang itsbat dalam perspektif ushul fikih. Penelitian dilakukan terhadap hasil-hasil putusan sidang itsbat penetapan awal Ramadhan dan Syawal pada tahun 1381 H - 1434 H/1962 M - 2011 M. Penelitian ini menyimpulkan bahwa kecenderungan terjadinya perbedaan disebabkan oleh ketinggian hilal dan pendekatan dalam menentukan bulan baru. Menurut ushul fikih, sidang itsbat dapat dilihat dalam beberapa perspektif; pertama, merupakan kewajiban pemerintah sebagai representasi imam atas rakyatnya. Yaitu untuk memfasilitasi dan mendukung pelaksanaan ibadah secara totalitas; Kedua, merupakan bentuk tanggung jawab negara kepada rakyatnya untuk menciptakan kebersamaan, terlebih dalam pelaksanaan ibadah umat seiman, dengan meminimalkan perbedaan pendapat dan konflik. Ketiga, untuk mengupayakan terwujudnya kemaslahatan bersama (maslahat 'âmmah) yang menjadi esensi dari maqāsid al-sharīah (tujuan syari'ah). Sidang itsbat merupakan salah satu contoh bentuk maslahat häjïyyah yang dibutuhkan demi menyempurnakan ibadah puasa Ramadhan, Idul Fitri, dan Idul Adha.

Keywords: sidang itsbat, hilal, ushul fikih, maslahat, bulan Qamariyah 


\section{Pendahuluan}

Penentuan awal bulan Qamariyah merupakan suatu persoalan yang sangat penting dalam agama Islam karena hal ini menyangkut pelaksanaan ibadah, khususnya pada bulan Ramadhan, terkait dengan penentuan kapan memulai dan mengakhiri ibadah puasa, serta bulan Syawal. Namun demikian, walaupun penetapan awal bulan baru ini merupakan persoalan yang sangat penting, dalam realitasnya seringkali terjadi perbedaan hari lebaran. Bahkan perbedaan tersebut seringkali menjadi penyebab terjadinya perseteruan dan mengusik ukhuwah islamiyah di antara sesama Muslim.

Hampir setiap tahun, di Indonesia terjadi perbedaan dalam penetapan awal Ramadhan atau Syawal. Perbedaan lebaran misalnya, terjadi pada masa Orde Baru pasca hadirnya Badan Hisab dan Rukyat (BHR), yaitu pada tahun 1985, 1992, 1993, dan 1998. Perbedaan ini kembali terulang pada tahun 2002, 2006, 2007 dan 2011. Keberadaan Badan Hisab dan Rukyat bertujuan untuk mengusahakan bersatunya umat Islam dalam menentukan tanggal 1 Ramadhan, 1 Syawal, dan 10 Dzulhijjah. Namun sampai saat ini dan pada tahun-tahun yang akan datang, nampaknya masih sangat mungkin terjadi perbedaan.

Di Indonesia, penetapan awal bulan Qamariyah berada di tangan Pemerintah melalui sebuah musyawarah yang dikenal dengan sebutan Sidang Itsbat. Dalam sidang itsbat ini pemerintah yang diwakili oleh Menteri Agama akan memutuskan kapan akan dimulai dan diakhiri puasa. Namun sayangnya, walaupun sidang itsbat telah berlangsung lama, perbedaan masih saja terjadi. Ada saja kelompok yang tidak mengikuti putusan sidang itsbat pemerintah. Bahkan, ada pula peserta yang ikut sidang itsbat bukan untuk mengikuti keputusan sidang, namun untuk izin berlebaran terlebih dahulu melaksanakan lebaran. Bila hal ini terus terjadi, maka tujuan sidang itsbat untuk menyeragamkan waktu ibadah tidak akan pernah akan terwujud.

Dalam paper ini, akan ditelaah secara kritis putusan sidang itsbat sejak tahun 1381 H - 1432 H/1962 M - 2011 M dalam penetapan awal bulan Ramadhan, Syawal dan Dzulhijjah dalam perspektif ushul fikih. Dengan telaah kritis tersebut diharapkan dapat mengetahui penyebab perbedaan yang seringkali terjadi, peran putusan sidang itsbat dalam penyatuan penetapan awal bulan Qamariyah, dan telaah putusan sidang itsbat awal bulan Qamariyah dalam perspektif ushul fikih. 


\section{Sidang Itsbat dan Urgensinya}

Itsbat dalam bahasa Arab berasal dari kata athbata - yuthbitu- ithbātan, yang berarti penetapan, pengukuhan, pengiyaan. ${ }^{1}$ Susiknan Azhari, dalam Ensiklopedi Hisab Rukyat, memberikan definisi itsbat (sidang itsbat) sebagai sidang untuk menetapkan kapan jatuhnya tanggal 1 Ramadhan, 1 Syawal, dan 1 Dzulhijjah yang dihadiri berbagai ormas Islam di Indonesia dan langsung dipimpin oleh Menteri Agama RI. ${ }^{2}$ Sidang itsbat dihadiri di antaranya oleh Duta Besar Negara-negara Islam, Pejabat Eselon I dan II Depag RI, Anggota BHR Kementerian Agama, MUI dan Ormas Islam, dan Lembaga/Instansi yang terkait.

Acara tersebut dipimpin langsung oleh Menteri Agama Republik Indonesia. Acara pokok sidang itsbat dimulai dengan presentasi/simulasi hisab awal bulan, dilanjutkan dengan tanggapan/saran (sambil menunggu laporan rukyat), dan diakhiri penetapan awal bulan. ${ }^{3}$ Menteri Agama dalam proses penetapan sidang itsbat, menimbang beberapa hal sebelum mengambil keputusan, yaitu data hisab yang dihimpun oleh Badan Hisab Rukyat Kementerian Agama dari berbagai sumber tentang waktu ijtima', ketinggian hilal dan posisi hilal di seluruh Indonesia, dan laporan pelaksanaan rukyat dari seluruh Indonesia. 4

Sidang itsbat sangat penting diadakan untuk memberikan kepastian kepada masyarakat terkait dengan penetapan tanggal 1 Ramadhan, Syawal dan Dzulhijjah. Dengan sidang itsbat yang menghimpun berbagai informasi baik hasil hisab maupun laporan rukyat dari seluruh titik observasi hilal di Indonesia, dapat memberikan kemantapan bagi umat Islam dalam melaksanakan ibadah. Apalagi, keputusan yang diambil dalam sidang itsbat ini merupakan hasil musyawarah Menteri Agama dengan anggota Badan Hisab Rukyat, ormas Islam dan para ahli, sehingga keberadaannya sangat ditunggu-tunggu masyarakat.

1Adib Bisri dan Munawwir A. Fatah, Kamus al-Bisri (Surabaya: Pustaka Progressif, 1999), h. 56.

2Susiknan Azhari, Ensiklopedi Hisab Rukyat, Cet. II (Yogyakarta: Pustaka Pelajar, 2008), h. 106.

${ }^{3}$ Muhyiddin Khazin, Makalah Teknik Pelaksanaan Rukyatul Hilal dan Sidang Itsbat (Subdit Pembinaan Syariah dan Hisab Rukyat Departemen Agama RI tahun 2008).

${ }^{4}$ Keputusan Menteri Agama Republik Indonesia tentang Penetapan Tanggal 1 Ramadhan, dan 1 Syawal. 


\section{Sejarah Perkembangan Badan Hisab Rukyat (BHR)}

Pada masa penjajahan, persoalan penentuan awal bulan yang berkaitan dengan ibadah diserahkan pada kerajaan-kerajaan Islam yang masih ada. Setelah Indonesia merdeka, secara berangsur-angsur mulai terjadi perubahan. Setelah terbentuk Departemen Agama pada tanggal 4 Januari 19465 , persoalanpersoalan yang berkaitan dengan hari libur (termasuk penetapan 1 Ramadhan, 1 Syawal dan 10 Dzulhijjah) diserahkan kepada Departemen Agama. Namun, walaupun penetapan hari libur telah diserahkan pada Departemen Agama, dalam wilayah praktis sampai saat ini (terkadang) masih belum seragam. Hal ini merupakan dampak dari adanya perbedaan antara beberapa pemahaman dalam wacana hisab rukyat. 6

Departemen Agama berinisiatif untuk mempertemukan perbedaan-perbedaan tersebut, sehingga dibentuklah Badan Hisab Rukyat Departemen Agama pada tanggal 16 Agustus 1972 yang diketuai oleh Sa'adoeddin Djambek.7 Sampai saat ini, badan tersebut (berubah menjadi Badan Hisab Rukyat Kementerian Agama) masih ada dan diketuai oleh Direktur URAIS Depag RI secara ex officio. ${ }^{8}$

Kehadiran Badan Hisab Rukyat adalah untuk menjaga persatuan dan ukhuwah islamiyah dalam beribadah, khususnya untuk mempersatukan paham ahli hisab dan rukyat dalam masyarakat Indonesia. Dengan kata lain, tujuan dari Badan Hisab Rukyat adalah mengusahakan bersatunya umat Islam dalam menentukan tanggal 1 Ramadhan, 1 Syawal, dan 10 Dzulhijjah. Statusnya adalah resmi dan berada di bawah Direktorat Jenderal Bimbingan Masyarakat Islam dan berkedudukan di Jakarta. Tugasnya memberi petunjuk dalam hal penentuan permulaan tanggal bulan Qamariyah kepada Menteri Agama. Keanggotaannya terdiri dari seorang anggota tetap (inti) yang mere-

\footnotetext{
${ }^{5}$ Harun Nasution, Ensiklopedi Islam Indonesia, cet. I (Jakarta: Djambatan, 1992), h. 211.

${ }^{6}$ Hampir setiap organisasi masyarakat termasuk Nahdlatul Ulama dan Muhammadiyah selalu mengeluarkan ketetapannya walaupun dalam bahasa yang lain seperti fatwa dan ikhbar. Lihat Susiknan Azhari, Sa'adoeddin Djambek (1911 - 1977) dalam Sejarah Pemikiran Hisab di Indonesia (Yogyakarta: IAIN Yogyakarta, 1999), h. 15.

${ }^{7}$ Hamdany Ali, Himpunan Keputusan Menteri Agama, cet I (Jakarta: Lembaga Lektur Keagamaan, 1972),h. 241.

8Ahmad Izzuddin, Fiqih Hisab Rukyat (Jakarta: Erlangga, 2007), h. 59.
} 
presentasikan tiga unsur, yaitu: 1) unsur Kementerian Agama, 2) unsur Ahli Falak/Hisab, 3) unsur Ahli Hukum Islam/Ulama. ${ }^{9}$

Sejak terbentuknya Badan Hisab Rukyah hingga saat ini telah mengalami banyak perkembangan dan penyempurnaan. Di antaranya dengan diadakannya musyawarah hisab dan rukyah antar negara Malaysia, Singapura dan Indonesia pada tanggal 19 sampai 11 Juli 1974 yang membahas tentang kerjasama dalam bidang hisab dan rukyah, yang selanjutnya dikembangkan dengan persoalan 10 Dzulhijjah kaitannya dengan hari wukuf di Arab Saudi. Di samping itu, Ketua Badan Hisab Rukyat juga menghadiri Konferensi penentuan awal bulan Hijriyah di Istanbul, Turki pada bulan November 1978 dalam rangka membangun kerjasama dengan negara lain..$^{10}$

Perkembangan berikutnya, Badan Hisab Rukyat telah dibentuk di daerahdaerah yang dikoordinasi oleh Pengadilan Tinggi Agama (PTA). Tugasnya adalah menghimpun para ahli hisab dan rukyat di daerah dan menyusun perhitungan hisab baik masalah arah kiblat, jadwal waktu shalat, dan sebagainya. Selanjutnya, pada tahun 1968 Kementerian Agama telah membangun Pos Observasi Bulan (POB) di Pelabuhan Ratu sebagai pusat observasi rukyat yang ada di Jakarta. Walaupun telah dibentuk Badan Hisab Rukyat dengan tugas untuk menyatukan hisab dan rukyat di Indonesia, dalam tataran riilnya masih belum terwujud, karena perbedaan penentuan awal Ramadhan maupun Idul Fitri masih sering terjadi.

Pada tahun-tahun terakhir, ada perbedaan dalam hal keberadaan Badan Hisab Rukyat pada masa sebelum era Susilo Bambang Yudhoyono (SBY) dan setelah era SBY. Pada masa Abdurrahman Wahid (Gus Dur) misalnya, Badan Hisab Rukyat tidak diberdayakan dan tidak dapat memberi kontribusi penyatuan. Gus Dur sebagaimana disampaikan Wahyu Widiana, bahkan mengatakan bahwa Badan Hisab Rukyat Departemen Agama akan dibubarkan dan persoalan hisab rukyat diserahkan kepada masyarakat. ${ }^{11}$

Pada era SBY, keberadaan Badan Hisab Rukyat diberdayakan kembali. Ini terbukti dengan adanya banyak upaya yang dilakukan Badan Hisab Rukyat

9Direktorat Jenderal Bimbingan Masyarakat Islam Kementerian Agama RI, Almanak Hisab Rukyat, 2010, h. 76.

10 Ibid, 81-88.

11 lbid. 
dalam rangka penyatuan awal bulan Qamariyah khususnya Ramadhan, Syawal dan Dzulhijjah. Berbagai upaya tersebut diantaranya, perekrutan anggota Badan Hisab Rukyat yang berasal dari para ahli hisab rukyat dan astronomi yang mewakili keberadaan masyarakat Indonesia, perumusan penyatuan kriteria hilal penetapan awal bulan Qamariyah, pembentukan Rancangan Undang-Undang Hisab Rukyat, dan sebagainya.

Era SBY juga ditandai dengan munculnya para pakar, tidak hanya para pakar hisab rukyat saja seperti Drs. H. Slamet Hambali, M.Si, Prof. Dr. Susiknan Azhari, Dr. H. Ahmad Izzuddin, M.Ag, dan lain-lain, namun para pakar astronomi juga banyak muncul dan memberikan perhatian cukup besar terhadap masalah hisab rukyat, seperti Prof. Dr. Bambang Hidayat, Prof. Ahmad Baiquni, M.Sc., P.h.D., Dr. Djoni N. Danawas, Dr. Moedji Raharto, dan Prof. Dr. Thomas Djamaluddin, M.Sc., dan lain-lain.

Di samping itu, pada era ini tampak wawasan masyarakat terbuka dan tercerahkan tentang perbedaan mengawali puasa Ramadhan, berhari raya Idul Fitri dan Idul Adha. Dengan terbukanya wawasan, masyarakat dapat lebih memahami perbedaan dan mengambil sikap untuk saling tasāmuh fi l-ikhtilāf (toleransi dalam perbedaan).

\section{Aliran Hisab Rukyat}

Wacana hisab rukyat khususnya penetapan awal bulan Qamariyah di Indonesia, terdapat dua aliran besar yang selama ini kuat yaitu aliran hisab dan aliran rukyat. Aliran hisab selalu diidentikkan dengan ormas Muhammadiyah, sedangkan aliran rukyat selalu diidentikkan dengan ormas Nahdlatul Ulama. Hal ini karena keduanya merupakan ormas keagamaan yang terbesar di Indonesia. Antara dua aliran ini seringkali terjadi perbedaan yang dilatarbelakangi oleh perbedaan pemahaman istilah rukyat dalam beberapa hadis Rasulullah.

Aliran hisab sendiri, terdapat beberapa perbedaan, yaitu sistem hisab taqrībì, tahqīqī dan kontemporer. Demikian pula dalam aliran rukyat terdapat beberapa perbedaan, yaitu rukyat global yang dipegangi oleh Hizbut Tahrir Indonesia, dan ru'yat fi wilāyat al-hukmi sebagaimana yang dipegangi oleh Nahdlatul Ulama.

Pada beberapa tahun terakhir, kurang lebih sejak tahun 2007, muncul aliran-aliran baru lain yang ikut mewarnai diskursus hisab rukyat di Indonesia, 
misalnya jamaah an-Nadzir, yang merukyat pasang surut air laut (bukan merukyat hilal) di Goa Sulawesi Selatan. Adapula yang menggunakan perhitungan yang disebut dengan golek limo yang dijadikan patokan oleh aliran Thariqah Naqsabandiyah. Selain aliran-aliran di atas, ada satu aliran lagi yang sudah ada sejak zaman kerajaan Islam, yaitu aliran Kejawen, mereka menggunakan perhitungan Aboge, penetapannya selalu berbeda satu hari setelah ketetapan pemerintah.

\section{Deskripsi Perbedaan Perhitungan Hisab Kementerian Agama}

Terdapat beberapa rujukan sistem hisab yang digunakan oleh Kementerian Agama. Berbagai rujukan inilah yang menjadikan perbedaan dalam perhitungan. Beberapa sistem hisab tersebut yaitu: 1) Hisab Haqīqī Taqrībì, dengan rujukan meliputi: Kitab Sullam al-Nayyirayn, Fath al-Ra'üf al-Mannān, al-Qawāidd alFalaqiyyah; 2) Hisab Haqīqī Tahqīqī, dengan rujukan meliputi: Hisāb Haqīqī, Badīat al-Mīthāl, al-Khulāsah al-Wäfiyah, al-Manāhij al-Hamīdiyyah, Nūr alAnwār, Menara Kudus; 3) Hisab Kontemporer, dengan rujukan meliputi: New Comb, Jeen Meus, E.W. Brouwn, Almanak Nautika, Ephemeris Hisab Rukyat, alFalaqiyyah, Mawāqīt, Ascript, Astro Info, Starry Night Pro $5 .{ }^{12}$

Berbagai sistem hisab tersebut, terdapat selisih yang cukup besar apabila dibandingkan dengan sistem hisab taqrībī, sebagaimana ditunjukkan tabel $1 \mathrm{di}$ bawah ini:

Tabel 1.

Rekap Hasil Perhitungan Ijtima' dan Tinggi Hilal Awal Syawal 2006/1427 H menurut Berbagai Macam Sistem

\begin{tabular}{|c|c|c|c|c|c|c|c|}
\hline \multirow{2}{*}{\multicolumn{2}{|c|}{ Sistem Hisab }} & \multirow{2}{*}{ No. } & \multirow{2}{*}{ Sistem } & \multicolumn{3}{|c|}{ ljtima' } & \multirow{2}{*}{$\begin{array}{c}\text { Tinggi } \\
\text { Hilal }\end{array}$} \\
\hline & & & & Hari & Tanggal & Jam & \\
\hline \multirow[t]{3}{*}{$\mathrm{I}$} & Hisāb Haqīqū & 1 & Sullamal-Nayyirayn & Ahad & 22 Okt. 2006 & 10.41 & $3^{0} 39^{\prime} 30^{\prime \prime}$ \\
\hline & Taqrībī & 2 & Fathal-Ra'ūfal-Mannān & Ahad & 220kt. 2006 & 11.14 & $3^{0} 23^{\prime}$ \\
\hline & & 3 & al-Qawā'idal-Falaqiyyah & Ahad & 220kt. 2006 & 12.08 & $1^{0} 48^{\prime}$ \\
\hline \multirow[t]{2}{*}{ II } & Hisāb Haqīqū & 4 & Hisāb Haqīqū & Ahad & 220kt. 2006 & 12.15 & $0^{0} 52^{\prime}$ \\
\hline & Tahquìqì & 5 & Badìatal-Mīthāl & Ahad & $220 k t .2006$ & 12.14 & $0^{0} 46^{\prime} 28^{\prime \prime}$ \\
\hline
\end{tabular}

12Keputusan Temu Kerja Evaluasi Hisab Rukyat Tahun 2006, tanggal 1-3 Juni 2006 di Hotel Ria Diani Bogor. 
Siti Tatmainul Qulub

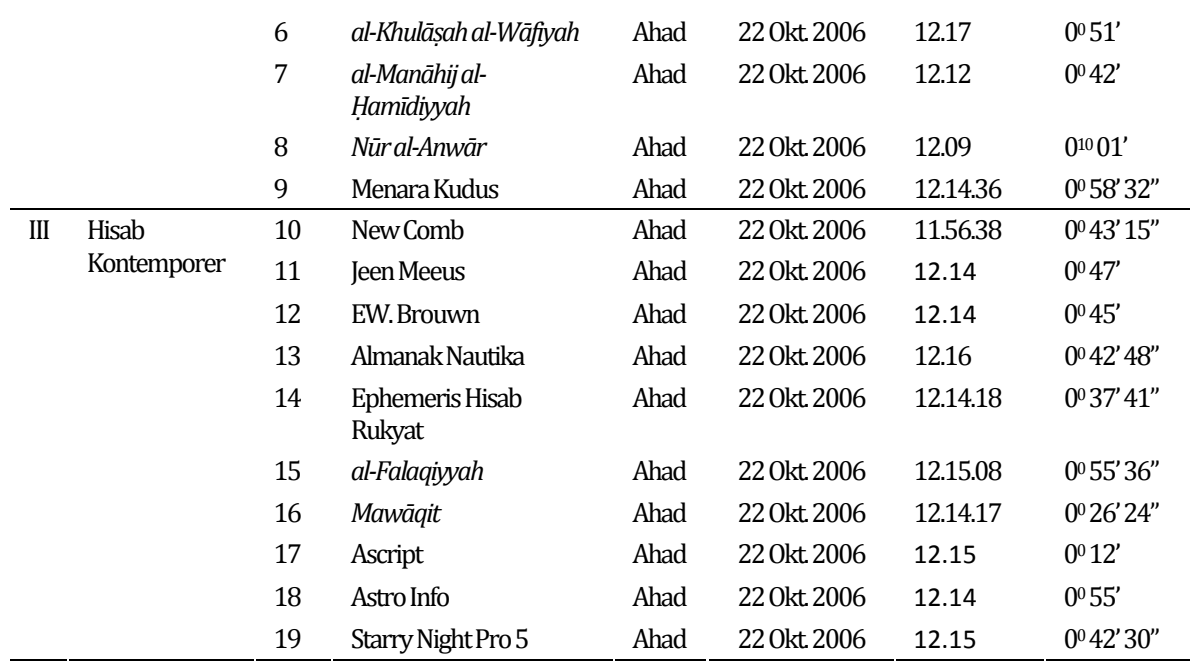

Keputusan Temu Kerja Evaluasi Hisab Rukyat Tahun 2006, tanggal 1-3 Juni 2006 di Hotel Ria Diani Bogor.

Adapun hisab resmi yang digunakan oleh pemerintah Indonesia mengacu pada sistem hisab Haqiqi Kontemporer yang berpedoman pada ufuk mar'i dengan menggunakan Kriteria MABIMS ${ }^{13}$, yaitu: 1) Tinggi hilal minimum $2^{0} ; 2$ ) Jarak dari matahari minimum 30;3) Umur bulan dihitung saat ijtimak atau bulan baru atau bulan dan matahari segaris bujur saat matahari terbenam minimal 8 jam. Kriteria ini sering disebut sebagai kriteria imkān al-ru'yat. Dasar dari kriteria imkān al-ru'yat $2^{0}$ yang digunakan pemerintah di atas adalah hilal Syawal $1424 \mathrm{H}$. Pada waktu itu tinggi hilal 20, ijtima' terjadi jam 10.18 WIB, 29 Juni 1984 yang dilihat oleh Muhammad Arief (Panitera Pengadilan Agama Pare-pare), Muhadir (Bendahara Pengadilan Pare-pare), H. Abdullah Hamid (Guru Agama Jakarta), H. Abdullah (Guru Agama Jakarta), K. Ma'mur (Guru Agama Sukabumi) dan Endang Effendi (Hakim Agama Sukabumi).14

Sedangkan sistem hisab rujukan pokok hisab Depag RI adalah Ephemeris hisab rukyat dengan Markas hisab POB Sukabumi Jawa Barat dengan posisi 70 01' 44,6" S, $106^{\circ} 33^{\prime}$ 27,8 BT dan ketinggian dari muka laut 52,69 meter.

\footnotetext{
13Direktorat Jenderal Bimbingan Masyarakat Islam Kementerian Agama Republik Indonesia tahun 2010, Almanak Hisab Rukyat, h. 42-43.

14Materi Sidang Anggota Badan Hisab Rukyat Departemen Agama RI tahun 2007.
} 
Adapun kalender resmi yang digunakan adalah Taqwim Standar Indonesia, yang merupakan Hasil Temu Kerja Evaluasi Hisab Rukyat Tahunan antara Kemenag, Nahdlatul Ulama' (NU), Muhammadiyah, Persatuan Islam (Persis), Dewan Dakwah Islam Indonesia (DDII), Al-Mansyuriyah, Obsevatorium Bosscha ITB, Lembaga Penerbangan dan Antariksa Nasional (LAPAN), Planetarium \& Observatorium Jakarta, Badan Meteorologi, Klimatologi dan Geofisika (BMKG), Bakosurtanal dan Ahli hisab rukyat perseorangan. ${ }^{15}$

\section{Hasil Sidang Itsbat sampai Tahun 2011}

Adapun hasil Sidang Itsbat dalam penetapan awal bulan Ramadhan dan Syawal pada tahun $1381 \mathrm{H}-1434$ H./1962 M - 2011 M adalah sebagaimana terrangkum dalam tabel 2 . Tabel tersebut menunjukkan bahwa dalam hasil keputusan terjadi beberapa kali perbedaan, khususnya antara Pemerintah dan Muhammadiyah. Dari data tersebut dapat teramati bahwa perbedaan seringkali terjadi pada saat posisi-posisi hilal awal bulan sedikit berada di atas ufuk yaitu antara $0^{\circ}-2^{\circ}$. Jika hilal berada di bawah ufuk (negatif) atau cukup tinggi (di atas $2^{\circ}$ ) biasanya perbedaan ini jarang terjadi. Hal ini karena kriteria yang digunakan oleh Muhammadiyah berbeda dengan pedoman dan kriteria yang ditetapkan oleh Pemerintah.

Tabel 2

Hasil Sidang Itsbat dari Tahun 1381 H/1962 M sampai tahun 1432 H/2011 M16

\begin{tabular}{|c|c|c|c|c|c|}
\hline $\begin{array}{c}\text { Tahun } \\
\text { H/M }\end{array}$ & Bulan & Ijtima' (WIB) & $\begin{array}{c}\text { Ketinggian } \\
\text { Hilal }\end{array}$ & Keputusan & Keterangan \\
\hline \multirow[t]{2}{*}{$1381 \mathrm{H} / 1962 \mathrm{M}$} & Ramadhan & $\begin{array}{l}\text { Senin, } 5 \\
\text { Feb1962 }\end{array}$ & $5^{\circ} 37^{\prime}$ & $\begin{array}{l}\text { Selasa, 6 Feb } \\
1962\end{array}$ & $\begin{array}{l}\text { Pelabuhan } \\
\text { Ratu, Sukabumi }\end{array}$ \\
\hline & Syawal & $\begin{array}{l}\text { Selasa, 6 Maret } \\
1962\end{array}$ & $0^{\circ} 43^{\prime}$ & $\begin{array}{l}\text { Kamis, 8 Maret } \\
1962\end{array}$ & Istikmal \\
\hline \multirow[t]{2}{*}{$1382 \mathrm{H} / 1963 \mathrm{M}$} & Ramadhan & $\begin{array}{l}\text { Jum'at, 25 Jan } \\
1963\end{array}$ & - & $\begin{array}{l}\text { Ahad, 27 Jan } \\
1963\end{array}$ & Istikmal \\
\hline & Syawal & $\begin{array}{l}\text { Ahad, 24 Feb } \\
1963\end{array}$ & $4^{\circ} 51^{\prime}$ & $\begin{array}{l}\text { Senin, 25 Feb } \\
1963\end{array}$ & - \\
\hline
\end{tabular}

15 Ibid.

16Kementerian Agama RI, "Keputusan Menteri Agama Republik Indonesia dalam Penetapan 1 Ramadhan, Syawal dan Dzulhijjah 1381 H-1432 H/1962 M-2011 M”, 2011. 
Siti Tatmainul Qulub

\begin{tabular}{|c|c|c|c|c|c|}
\hline \multirow[t]{2}{*}{$1383 / 1964 \mathrm{M}$} & Ramadhan & $\begin{array}{l}\text { Rabu, } 15 \text { Jan } \\
1964\end{array}$ & - & $\begin{array}{l}\text { Kamis, 16 Jan } \\
1964\end{array}$ & $\begin{array}{l}\text { Kampung } \\
\text { Bandan Ancol }\end{array}$ \\
\hline & Syawal & $\begin{array}{l}\text { Jum'at, 13 Feb } \\
1964\end{array}$ & - & $\begin{array}{l}\text { Sabtu, 15 Feb } \\
1964\end{array}$ & Istikmal \\
\hline \multirow[t]{3}{*}{$1384 / 1965 \mathrm{M}$} & Ramadhan & $\begin{array}{l}3 \operatorname{Jan} 1965 \\
\text { (02:32 WIB) }\end{array}$ & & Senin, 4 Jan 1965 & - \\
\hline & Syawal & $\begin{array}{l}\text { Senin, } 1 \text { Feb } \\
1965\end{array}$ & - & Rabu, 3 Feb 1965 & Istikmal \\
\hline & & (21:36 WIB) & & & \\
\hline \multirow[t]{3}{*}{$1385 / 1966 \mathrm{M}$} & Ramadhan & $\begin{array}{l}\text { Kamis, 23 Des } \\
1965\end{array}$ & $7^{\circ} 11^{\prime}$ & $\begin{array}{l}\text { Jum'at, 24 Des } \\
1965\end{array}$ & - \\
\hline & & (03:15 WIB) & & & \\
\hline & Syawal & $\begin{array}{l}\text { 21 Jan } 1966 \\
\text { (21:10 WIB) }\end{array}$ & - & $\begin{array}{l}\text { Jum'at, 23 Jan } \\
1966\end{array}$ & Istikmal \\
\hline \multirow[t]{2}{*}{ 1386/1967 M } & Ramadhan & $\begin{array}{l}\text { Senin, } 12 \text { Des } \\
1966\end{array}$ & & $\begin{array}{l}\text { Selasa, 13 Des } \\
1966\end{array}$ & $\begin{array}{l}\text { Kelapa Gading, } \\
\text { Puncak Tugu } \\
\text { Nasional }\end{array}$ \\
\hline & Syawal & $\begin{array}{l}\text { Selasa, 10 Jan } \\
1967\end{array}$ & - & $\begin{array}{l}\text { Kamis, 12 Jan } \\
1967\end{array}$ & Istikmal \\
\hline \multirow[t]{2}{*}{ 1387/1968 M } & Ramadhan & - & - & Ahad, 3 Des 1967 & \\
\hline & Syawal & - & - & Senin, 1 Jan 1968 & \\
\hline \multirow[t]{2}{*}{ 1388/1968 M } & Ramadhan & $\begin{array}{l}\text { Rabu, } 20 \text { Nov } \\
1968\end{array}$ & $1^{\circ}$ & $\begin{array}{l}\text { Jum'at, } 22 \text { Nov } \\
1968\end{array}$ & \\
\hline & Syawal & $\begin{array}{l}\text { Jum'at, 20 Des } \\
1968\end{array}$ & $8^{\circ}$ & $\begin{array}{l}\text { Sabtu, 21 Des } \\
1968\end{array}$ & \\
\hline \multirow[t]{2}{*}{$1389 / 1969 \mathrm{M}$} & Ramadhan & $\begin{array}{l}\text { Senin, } 10 \text { Nov } \\
1969\end{array}$ & $6^{\circ} 25^{\prime}$ & $\begin{array}{l}\text { Selasa, } 11 \text { Nov } \\
1969\end{array}$ & $\begin{array}{l}\text { Jakarta, Bekasi, } \\
\text { Pelabuhan Ratu }\end{array}$ \\
\hline & Syawal & $\begin{array}{l}\text { Selasa, 9 Des } \\
1969\end{array}$ & $\begin{array}{c}\text { kurang dari } \\
1^{\circ}\end{array}$ & $\begin{array}{l}\text { Kamis, } 11 \text { Des } \\
1969\end{array}$ & \\
\hline \multirow[t]{2}{*}{$1390 / 1970 \mathrm{M}$} & Ramadhan & $\begin{array}{l}\text { Jum'at, 30 Okt } \\
1970\end{array}$ & $2^{\circ} 47^{\prime}$ & $\begin{array}{l}\text { Sabtu, 31 Okt } \\
1970\end{array}$ & Jakarta \\
\hline & Syawal & $\begin{array}{l}\text { Ahad, 29 Nov } \\
1970\end{array}$ & $7^{\circ}$ & $\begin{array}{l}\text { Senin, 30 Nov } \\
1970\end{array}$ & \\
\hline \multirow[t]{2}{*}{ 1391/1971 M } & Ramadhan & $\begin{array}{l}\text { Selasa, 19 Okt } \\
1971\end{array}$ & & $\begin{array}{l}\text { Kamis, 21 Okt } \\
1971\end{array}$ & Istimal \\
\hline & Syawal & $\begin{array}{l}\text { Kamis, } 18 \text { Nov } \\
1971\end{array}$ & $6^{\circ}$ & $\begin{array}{l}\text { Jum'at, } 19 \text { Nov } \\
1971\end{array}$ & \\
\hline \multirow[t]{2}{*}{$1392 / 1972 \mathrm{M}$} & Ramadhan & $\begin{array}{l}\text { Sabtu, 7 Okt } \\
1972\end{array}$ & - & Senin, 9 Okt 1972 & Istikmal \\
\hline & Syawal & $\begin{array}{l}\text { Senin, } 6 \text { Nov } \\
1972\end{array}$ & $5^{\circ}$ & $\begin{array}{l}\text { Selasa, } 7 \text { Nov } \\
1972\end{array}$ & Ancol, Bekasi \\
\hline \multirow[t]{2}{*}{$1393 / 1973 \mathrm{M}$} & Ramadhan & $\begin{array}{l}\text { Rabu, 16 Sept } \\
1973\end{array}$ & & $\begin{array}{l}\text { Jum'at, 28Sept } \\
1973\end{array}$ & Istikmal \\
\hline & Syawal & $\begin{array}{l}\text { Jum'at, 26 Okt } \\
1973\end{array}$ & $3^{\circ}$ & $\begin{array}{l}\text { Sabtu, 27 Okt } \\
1973\end{array}$ & $\begin{array}{l}\text { Ancol Tiang } \\
\text { Priok, Bekasi }\end{array}$ \\
\hline
\end{tabular}


Telaah Kritis Putusan Sidang Isbat ....

\begin{tabular}{|c|c|c|c|c|c|}
\hline \multirow[t]{2}{*}{ 1394/1974 M } & Ramadhan & $\begin{array}{l}\text { Senin,16 Sept } \\
1974\end{array}$ & & $\begin{array}{l}\text { Selasa, 17 Sept } \\
1974\end{array}$ & $\begin{array}{l}\text { Jakarta, } \\
\text { Yogyakarta }\end{array}$ \\
\hline & Syawal & $\begin{array}{l}\text { Selasa, 15 Okt } \\
1974\end{array}$ & - & $\begin{array}{l}\text { Kamis, } 17 \text { Okt } \\
1974\end{array}$ & Istikmal \\
\hline \multirow[t]{2}{*}{$1395 / 1975 \mathrm{M}$} & Ramadhan & $\begin{array}{l}\text { Sabtu, 6Sept } \\
1975\end{array}$ & - & $\begin{array}{l}\text { Ahad,7 Sept } \\
1975\end{array}$ & $\begin{array}{l}\text { Jakarta, Bekasi, } \\
\text { Sukabumi }\end{array}$ \\
\hline & Syawal & $\begin{array}{l}\text { Ahad,5 Okt } \\
1975\end{array}$ & & Senin, 6 Okt 1975 & Jakarta, Bekasi \\
\hline \multirow[t]{2}{*}{ 1396/1976 M } & Ramadhan & $\begin{array}{l}\text { Rabu, } 25 \\
\text { Agustus } 1976\end{array}$ & - & $\begin{array}{l}\text { Jum'at, 27 Agt. } \\
1976\end{array}$ & Istikmal \\
\hline & Syawal & $\begin{array}{l}\text { Jum'at, 24 Sept } \\
1976\end{array}$ & - & $\begin{array}{l}\text { Sabtu, 25 Sept } \\
1976\end{array}$ & \\
\hline \multirow[t]{2}{*}{$1397 / 1977 \mathrm{M}$} & Ramadhan & $\begin{array}{l}\text { Senin, } 15 \\
\text { Agustus } 1977\end{array}$ & & $\begin{array}{l}\text { Selasa, 16 Agt. } \\
1977\end{array}$ & $\begin{array}{l}\text { Jakarta, } \\
\text { Sukabumi }\end{array}$ \\
\hline & Syawal & $\begin{array}{l}\text { Selasa, 13 Sept } \\
1977\end{array}$ & $\begin{array}{c}-0.5^{\circ} \text { sampai } \\
-1.56^{\circ}\end{array}$ & $\begin{array}{l}\text { Kamis, 15 Sept } \\
1977\end{array}$ & Istikmal \\
\hline \multirow[t]{2}{*}{ 1398/1978 M } & Ramadhan & $\begin{array}{l}\text { Jum'at, 4 Agt. } \\
1978\end{array}$ & & Sabtu, 5 Agt. 1978 & $\begin{array}{l}\text { Jakarta, } \\
\text { Sukabumi, } \\
\text { Brebes }\end{array}$ \\
\hline & Syawal & $\begin{array}{l}\text { Sabtu, } 2 \text { Sept } \\
1978\end{array}$ & $\begin{array}{c}-3^{\circ} 26^{\prime} 56^{\prime \prime} \\
\text { sampai -4 } \\
47^{\prime} 44^{\prime \prime}\end{array}$ & $\begin{array}{l}\text { Senin, 4 Sept } \\
1978\end{array}$ & Istikmal \\
\hline \multirow[t]{2}{*}{ 1399/1979 M } & Ramadhan & $\begin{array}{l}\text { Selasa, 24 Juli } \\
1979\end{array}$ & & $\begin{array}{l}\text { Rabu, 25 Juli } \\
1979\end{array}$ & $\begin{array}{l}\text { Jakarta, } \\
\text { Sukabumi, } \\
\text { Purwakarta }\end{array}$ \\
\hline & Syawal & $\begin{array}{l}\text { Rabu, } 22 \text { Agt. } \\
1979\end{array}$ & $\begin{array}{c}-3^{\circ} 35^{\prime} \\
\text { sampai - } \\
4^{\circ} 56^{\prime}\end{array}$ & $\begin{array}{l}\text { Jum'at, 24 Agt. } \\
1979\end{array}$ & Istikmal \\
\hline \multirow[t]{2}{*}{$1400 / 1980 \mathrm{M}$} & Ramadhan & $\begin{array}{l}\text { Sabtu, 12 Juli } \\
1980\end{array}$ & - & $\begin{array}{l}\text { Senin, 14 Juli } \\
1980\end{array}$ & Istikmal \\
\hline & Syawal & $\begin{array}{l}\text { Senin, } 11 \text { Agt. } \\
1980\end{array}$ & - & $\begin{array}{l}\text { Selasa, } 12 \text { Agt. } \\
1980\end{array}$ & $\begin{array}{l}\text { Mataram, } \\
\text { Sukabumi, } \\
\text { Jakarta }\end{array}$ \\
\hline \multirow[t]{2}{*}{ 1401/1981 M } & Ramadhan & $\begin{array}{l}\text { Kamis, } 2 \text { Juli } \\
1981\end{array}$ & & Jum'at, 3 Juli 1981 & $\begin{array}{l}\text { Pelabuhan } \\
\text { Ratu, } \\
\text { Sukabumi, } \\
\text { Situbondo }\end{array}$ \\
\hline & Syawal & $\begin{array}{l}\text { Jum'at, 31 Juli } \\
1981\end{array}$ & & Sabtu, 1 Agt. 1981 & $\begin{array}{l}\text { Jakarta Selatan, } \\
\text { Jakarta Timur }\end{array}$ \\
\hline \multirow[t]{2}{*}{$1402 / 1982 \mathrm{M}$} & Ramadhan & $\begin{array}{l}\text { Senin, 21 Juni } \\
1982\end{array}$ & & $\begin{array}{l}\text { Rabu, 23 Juni } \\
1982\end{array}$ & Istikmal \\
\hline & Syawal & $\begin{array}{l}\text { Rabu, 21 Juli } \\
1982\end{array}$ & - & $\begin{array}{l}\text { Kamis, 22 Juli } \\
1982\end{array}$ & $\begin{array}{l}\text { Ternate, } \\
\text { Ampenan, } \\
\text { Sukabumi dan } \\
\text { daerah lainnya }\end{array}$ \\
\hline $1403 / 1983 \mathrm{M}$ & Ramadhan & $\begin{array}{l}\text { Sabtu, 11 Juni } \\
1983\end{array}$ & & $\begin{array}{l}\text { Ahad, 12 Juni } \\
1983\end{array}$ & $\begin{array}{l}\text { Pelabuhan } \\
\text { Ratu, } \\
\text { Sukabumi, } \\
\text { Cakung }\end{array}$ \\
\hline
\end{tabular}


Siti Tatmainul Qulub

\begin{tabular}{|c|c|c|c|c|c|}
\hline & Syawal & $\begin{array}{l}\text { Ahad, 10 Juli } \\
1983\end{array}$ & & $\begin{array}{l}\text { Selasa, 12 Juli } \\
1983\end{array}$ & Istikmal \\
\hline \multirow[t]{2}{*}{$1404 / 1984 \mathrm{M}$} & Ramadhan & $\begin{array}{l}\text { Rabu, 30 Mei } \\
1984\end{array}$ & $\begin{array}{c}-4^{\circ} \text { sampai - } \\
6^{\circ}\end{array}$ & $\begin{array}{l}\text { Jum'at, 1 Juni } \\
1984\end{array}$ & Istikmal \\
\hline & Syawal & $\begin{array}{l}\text { Jum'at, 29 Juni } \\
1984\end{array}$ & & $\begin{array}{l}\text { Sabtu, 30 Juni } \\
1984\end{array}$ & $\begin{array}{l}\text { Pare-Pare, } \\
\text { Cakung, } \\
\text { Pelabuhan Ratu }\end{array}$ \\
\hline \multirow[t]{2}{*}{$1405 / 1985 \mathrm{M}$} & Ramadhan & $\begin{array}{l}\text { Senin, } 20 \text { Mei } \\
1985\end{array}$ & - & $\begin{array}{l}\text { Selasa, } 21 \text { Mei } \\
1985\end{array}$ & - \\
\hline & Syawal & $\begin{array}{l}\text { Selasa, 18 Juni } \\
1985\end{array}$ & $1^{\circ}$ & $\begin{array}{l}\text { Kamis, 20 Juni } \\
1985\end{array}$ & - \\
\hline \multirow[t]{2}{*}{$1406 / 1986 \mathrm{M}$} & Ramadhan & $\begin{array}{l}\text { Jum'at, 9 Mei } \\
1986\end{array}$ & - & $\begin{array}{l}\text { Sabtu, } 10 \text { Mei } \\
1986\end{array}$ & - \\
\hline & Syawal & $\begin{array}{l}\text { Sabtu, 7 Juni } \\
1986\end{array}$ & $\begin{array}{c}-2^{\circ} \text { sampai - } \\
4^{\circ}\end{array}$ & Senin, 9 Juni 1986 & Istikmal \\
\hline \multirow[t]{2}{*}{$1407 / 1987 \mathrm{M}$} & Ramadhan & $\begin{array}{l}\text { Selasa, 28 April } \\
1987\end{array}$ & $2^{\circ}$ & $\begin{array}{l}\text { Rabu, 29 April } \\
1987\end{array}$ & Pelabuhan Ratu \\
\hline & Syawal & $\begin{array}{l}\text { Rabu, 27 Mei } \\
1987\end{array}$ & $\begin{array}{c}-2^{\circ} \text { sampai - } \\
5^{\circ}\end{array}$ & $\begin{array}{l}\text { Jum'at, 29 Mei } \\
1987\end{array}$ & $\begin{array}{l}\text { Pelabuhan } \\
\text { Ratu, Jakarta } \\
\text { Timur }\end{array}$ \\
\hline \multirow[t]{2}{*}{$1408 / 1988 \mathrm{M}$} & Ramadhan & $\begin{array}{l}\text { Sabtu, 16 April } \\
1988\end{array}$ & & $\begin{array}{l}\text { Senin, 18 April } \\
1988\end{array}$ & $\begin{array}{l}\text { Jakarta Timur, } \\
\text { Klender }\end{array}$ \\
\hline & Syawal & $\begin{array}{l}\text { Senin, } 16 \text { Mei } \\
1988\end{array}$ & & $\begin{array}{l}\text { Selasa, } 17 \text { Mei } \\
1988\end{array}$ & $\begin{array}{l}\text { Cakung, } \\
\text { Klender }\end{array}$ \\
\hline \multirow[t]{2}{*}{ 1409/1989 M } & Ramadhan & $\begin{array}{l}\text { Kamis, 6 April } \\
1989\end{array}$ & & $\begin{array}{l}\text { Jum'at, } 7 \text { April } \\
1989\end{array}$ & Jakarta Timur \\
\hline & Syawal & $\begin{array}{l}\text { Jum'at, } 5 \text { Mei } \\
1989\end{array}$ & $\begin{array}{c}-2^{\circ} \text { sampai - } \\
4^{\circ}\end{array}$ & Ahad, 7 Mei 1989 & Gresik, Cakung \\
\hline \multirow[t]{2}{*}{$1410 / 1990 \mathrm{M}$} & Ramadhan & $\begin{array}{l}\text { Selasa, } 27 \\
\text { Maret } 1990\end{array}$ & & $\begin{array}{l}\text { Rabu, 28 Maret } \\
1990\end{array}$ & $\begin{array}{l}\text { Pelabuhan } \\
\text { Ratu, Bekasi }\end{array}$ \\
\hline & Syawal & $\begin{array}{l}\text { Rabu, } 25 \text { April } \\
1990\end{array}$ & & $\begin{array}{l}\text { Kamis, 26 April } \\
1990\end{array}$ & $\begin{array}{l}\text { Ujung Pangkah, } \\
\text { Gresik, Cakung, } \\
\text { Jakarta Timur }\end{array}$ \\
\hline \multirow[t]{2}{*}{$1411 / 1991 \mathrm{M}$} & Ramadhan & $\begin{array}{l}\text { Kamis, } 16 \\
\text { Maret } 1991\end{array}$ & $\begin{array}{c}-0.5^{\circ} \text { sampai } \\
-2.5^{\circ}\end{array}$ & $\begin{array}{l}\text { Sabtu, 18 Maret } \\
1991\end{array}$ & Istikmal \\
\hline & Syawal & $\begin{array}{l}\text { Senin, } 15 \text { April } \\
1991\end{array}$ & & $\begin{array}{l}\text { Selasa, 16 April } \\
1991\end{array}$ & $\begin{array}{l}\text { Cakung, } \\
\text { Klender, } \\
\text { Kembangan, } \\
\text { Pelabuhan Ratu }\end{array}$ \\
\hline \multirow[t]{2}{*}{$1412 / 1992 \mathrm{M}$} & Ramadhan & $\begin{array}{l}\text { Rabu, } 4 \text { Maret } \\
1992\end{array}$ & $\begin{array}{c}-3^{\circ} \text { sampai - } \\
5^{\circ}\end{array}$ & $\begin{array}{l}\text { Jum'at, 6 Maret } \\
1992\end{array}$ & Istikmal \\
\hline & Syawal & $\begin{array}{l}\text { Jum'at, } 3 \text { April } \\
1992\end{array}$ & $-2^{\circ}$ & $\begin{array}{l}\text { Ahad, } 5 \text { April } \\
1992\end{array}$ & Istikmal \\
\hline \multirow[t]{2}{*}{$1413 / 1993 \mathrm{M}$} & Ramadhan & $\begin{array}{l}\text { Ahad, 21 Feb } \\
1993\end{array}$ & $\begin{array}{c}-2.5^{\circ} \text { sampai } \\
-4.5^{\circ}\end{array}$ & $\begin{array}{l}\text { Selasa, 23 Feb } \\
1993\end{array}$ & Istikmal \\
\hline & Syawal & $\begin{array}{l}\text { Selasa, } 23 \\
\text { Maret } 1993\end{array}$ & $-2.5^{\circ}$ & $\begin{array}{l}\text { Kamis, } 25 \text { Maret } \\
1993\end{array}$ & Istikmal \\
\hline
\end{tabular}


Telaah Kritis Putusan Sidang Isbat ....

\begin{tabular}{|c|c|c|c|c|c|}
\hline \multirow[t]{2}{*}{$1414 / 1994 \mathrm{M}$} & Ramadhan & $\begin{array}{l}\text { Kamis, 20 Feb } \\
1994\end{array}$ & $\begin{array}{c}-3.5^{\circ} \text { sampai } \\
-6^{\circ}\end{array}$ & $\begin{array}{l}\text { Sabtu, 12 Feb } \\
1994\end{array}$ & Istikmal \\
\hline & Syawal & $\begin{array}{l}\text { Sabtu, } 12 \text { Maret } \\
1994\end{array}$ & $-3^{\circ}$ & $\begin{array}{l}\text { Senin, } 14 \text { Maret } \\
1994\end{array}$ & Istikmal \\
\hline \multirow[t]{2}{*}{$1415 / 1995 \mathrm{M}$} & Ramadhan & $\begin{array}{l}\text { Selasa, 31 Jan } \\
1995\end{array}$ & & Rabu, 1 Feb 1995 & $\begin{array}{l}\text { Manado, } \\
\text { Pelabuhan } \\
\text { Ratu, Sukabumi }\end{array}$ \\
\hline & Syawal & $\begin{array}{l}\text { Rabu, 1 Maret } \\
1995\end{array}$ & $\begin{array}{c}-2^{\circ} \text { sampai - } \\
4^{\circ}\end{array}$ & $\begin{array}{l}\text { Jum'at, } 3 \text { Maret } \\
1995\end{array}$ & Istikmal \\
\hline \multirow[t]{2}{*}{$1416 / 1996 \mathrm{M}$} & Ramadhan & $\begin{array}{l}\text { Sabtu, 20 Jan } \\
1996\end{array}$ & $\begin{array}{c}-2^{\circ} \text { sampai - } \\
4.5^{\circ}\end{array}$ & $\begin{array}{l}\text { Senin, 22 Jan } \\
1996\end{array}$ & Istikmal \\
\hline & Syawal & $\begin{array}{l}\text { Senin, 19 Feb } \\
1996\end{array}$ & - & $\begin{array}{l}\text { Selasa, 20 Feb } \\
1996\end{array}$ & $\begin{array}{l}\text { Pelabuhan } \\
\text { Ratu, Bekasi, } \\
\text { Gresik, Jakarta } \\
\text { Barat }\end{array}$ \\
\hline \multirow[t]{2}{*}{$1417 / 1997 \mathrm{M}$} & Ramadhan & $\begin{array}{l}\text { Kamis, 9 Jan } \\
1997\end{array}$ & $\begin{array}{c}0.3^{\circ} \text { sampai - } \\
3^{\circ}\end{array}$ & $\begin{array}{l}\text { Jum'at, 10 Jan } \\
1997\end{array}$ & $\begin{array}{l}\text { Gorontalo, } \\
\text { Rembang }\end{array}$ \\
\hline & Syawal & $\begin{array}{l}\text { Jum'at, 7 Feb } \\
1997\end{array}$ & $\begin{array}{c}-1.5^{\circ} \text { sampai } \\
-6.5^{\circ}\end{array}$ & Ahad, 9Feb 1997 & Istikmal \\
\hline \multirow[t]{2}{*}{ 1418/1998M } & Ramadhan & $\begin{array}{l}\text { Senin, 29 Des } \\
1997 \\
(23: 34 \text { WIB })\end{array}$ & $\begin{array}{c}-4^{\circ} \text { sampai - } \\
7^{\circ}\end{array}$ & $\begin{array}{l}\text { Rabu, 31 Des } \\
1997\end{array}$ & Istikmal \\
\hline & Syawal & $\begin{array}{l}\text { Rabu, 28 Jan } \\
1998\end{array}$ & $0_{45^{\circ}}^{\circ}$ & $\begin{array}{l}\text { Jum'at, 30 Jan } \\
1998\end{array}$ & Istikmal \\
\hline \multirow[t]{2}{*}{ 1419/1999 M } & Ramadhan & $\begin{array}{l}\text { Sabtu, 19 Des } \\
1998 \\
(04: 39 \text { WIB })\end{array}$ & $\begin{array}{c}-5.5^{\circ} \text { sampai } \\
-7.5^{\circ}\end{array}$ & $\begin{array}{l}\text { Ahad, 20 Des } \\
1998\end{array}$ & Istikmal \\
\hline & Syawal & $\begin{array}{l}\text { Ahad, 17 Jan } \\
1999 \\
\text { (21:41 WIB) }\end{array}$ & $\begin{array}{c}-4^{\circ} 59^{\prime} \\
\text { sampai }-3^{\circ} \\
13^{\prime}\end{array}$ & $\begin{array}{l}\text { Selasa, 19 Jan } \\
1999\end{array}$ & Istikmal \\
\hline \multirow[t]{2}{*}{$1420 / 2000 \mathrm{M}$} & Ramadhan & $\begin{array}{l}\text { Rabu, 8Des } \\
1999 \\
\text { (09.38WIB) }\end{array}$ & $\begin{array}{c}3^{\circ} 42^{\prime} \\
\text { sampai } 5^{\circ} \\
23^{\prime}\end{array}$ & $\begin{array}{l}\text { Kamis, 9 Des } \\
1999\end{array}$ & \\
\hline & Syawal & $\begin{array}{l}\text { Kamis, 6 Jan } \\
2000 \\
\text { (23:47 WIB) }\end{array}$ & $\begin{array}{c}-5^{\circ} 32^{\prime} \\
\text { sampai }-3^{\circ} \\
56^{\prime}\end{array}$ & Sabtu, 8 Jan 2000 & Istikmal \\
\hline \multirow[t]{2}{*}{$1421 / 2000 \mathrm{M}$} & Ramadhan & $\begin{array}{l}\text { Ahad, } 26 \text { Nov } \\
2000 \\
(06: 05 \text { WIB) }\end{array}$ & $\begin{array}{c}31 / 2^{\circ} \\
\text { sampai } \\
\text { dengan } 5^{\circ}\end{array}$ & $\begin{array}{l}\text { Senin, } 27 \text { Nov } \\
2000\end{array}$ & \\
\hline & Syawal & $\begin{array}{l}\text { Senin, 25 Des } \\
2000\end{array}$ & $\begin{array}{c}-5^{\circ} \text { sampai - } \\
3^{\circ}\end{array}$ & $\begin{array}{l}\text { Rabu, 27 Des } \\
2000\end{array}$ & \\
\hline \multirow[t]{2}{*}{$1422 / 2001 \mathrm{M}$} & Ramadhan & $\begin{array}{l}\text { Kamis, } 15 \text { Nov } \\
2001 \\
(13: 41 \text { WIB })\end{array}$ & $\begin{array}{c}0^{\circ} 20^{\prime} \\
\text { sampai } 2^{\circ} \\
20^{\prime}\end{array}$ & $\begin{array}{l}\text { Sabtu, } 17 \text { Nov } \\
2001\end{array}$ & \\
\hline & Syawal & $\begin{array}{l}\text { Sabtu, 15 Des } \\
2001 \\
(03: 48 \text { WIB })\end{array}$ & $\begin{array}{c}5^{\circ} \text { sampai } \\
6.5^{\circ}\end{array}$ & $\begin{array}{l}\text { Ahad, 16 Des } \\
2001\end{array}$ & \\
\hline
\end{tabular}


Siti Tatmainul Qulub

\begin{tabular}{|c|c|c|c|c|c|}
\hline \multirow[t]{2}{*}{$1423 / 2002 \mathrm{M}$} & Ramadhan & $\begin{array}{l}\text { Selasa, } 5 \text { Nov } \\
2002 \\
(03: 34 \text { WIB })\end{array}$ & $\begin{array}{c}61 / 2^{\circ} \\
\text { sampai } 7 / .5^{\circ}\end{array}$ & Rabu, 6 Nov 2002 & \\
\hline & Syawal & $\begin{array}{l}\text { Rabu, 4 Des } \\
2002 \\
(14: 34 \text { WIB })\end{array}$ & $\begin{array}{c}-0.30^{\circ} \\
\text { sampai }^{\circ} \\
15^{\prime}\end{array}$ & $\begin{array}{l}\text { Jum'at, 16 Des } \\
2002\end{array}$ & \\
\hline \multirow[t]{2}{*}{$1424 / 2003 \mathrm{M}$} & Ramadhan & $\begin{array}{l}\text { Sabtu, } 25 \text { Okt } \\
2003 \\
(19: 51 \text { WIB })\end{array}$ & $\begin{array}{c}-3^{\circ} \text { sampai - } \\
1^{\circ}\end{array}$ & $\begin{array}{l}\text { Senin, } 27 \text { Okt } \\
2003\end{array}$ & \\
\hline & Syawal & $\begin{array}{l}\text { Senin, } 24 \text { Nov } \\
2003 \\
(05: 57 \text { WIB })\end{array}$ & $4^{\circ}$ sampai $6^{\circ}$ & $\begin{array}{l}\text { Selasa, } 25 \text { Nov } \\
2003\end{array}$ & \\
\hline \multirow[t]{2}{*}{$1425 / 2004 \mathrm{M}$} & Ramadhan & $\begin{array}{l}\text { Kamis, } 14 \text { Okt } \\
2002 \\
(09: 48 \text { WIB })\end{array}$ & $2^{\circ}$ sampai $4^{\circ}$ & $\begin{array}{l}\text { Jum'at, 15 Okt } \\
2004\end{array}$ & \\
\hline & Syawal & $\begin{array}{l}\text { Jum'at, } 12 \text { Nov } \\
2004 \\
\text { (21:27 WIB) }\end{array}$ & $\begin{array}{c}-03^{\circ} 10^{\prime} \\
\text { sampai }-4^{\circ} \\
46^{\prime}\end{array}$ & $\begin{array}{l}\text { Ahad, 14 Nov } \\
2004\end{array}$ & \\
\hline \multirow[t]{2}{*}{$1426 \mathrm{H} / 2005 \mathrm{M}$} & Ramadhan & $\begin{array}{l}\text { Senin, } 03 \text { Okt } \\
2005 \\
(17: 28 \mathrm{WIB})\end{array}$ & $\begin{array}{c}-0^{\circ} 30^{\prime} \mathrm{s} / \mathrm{d} \\
-2^{\circ} 30^{\prime}\end{array}$ & Rabu, 5 Okt 2005 & Istikmal \\
\hline & Syawal & $\begin{array}{l}\text { Rabu, } 2 \text { Nov } \\
2005 \\
(08: 25 \text { WIB })\end{array}$ & $\begin{array}{c}1^{\circ} 30^{\prime} \mathrm{s} / \mathrm{d} \\
3^{\circ}\end{array}$ & $\begin{array}{l}\text { Kamis, } 3 \text { Nov } \\
2005\end{array}$ & $\begin{array}{l}\text { Rukyat Cakung } \\
\text { dan Gresik }\end{array}$ \\
\hline \multirow[t]{2}{*}{$1427 \mathrm{H} / 2006 \mathrm{M}$} & Ramadhan & $\begin{array}{l}\text { Jum'at, 22 Sept } \\
2006 \\
(18: 46 \text { WIB })\end{array}$ & $\begin{array}{l}-2^{\circ} \mathrm{s} / \mathrm{d} \\
-1^{\circ} 30^{\prime}\end{array}$ & $\begin{array}{l}\text { Ahad, 24 Sept } \\
2006\end{array}$ & Istikmal \\
\hline & Syawal & $\begin{array}{l}\text { Ahad, } 22 \text { Okt } \\
2006 \\
(12: 14 \text { WIB })\end{array}$ & $\begin{array}{c}-0^{\circ} 30^{\prime} \mathrm{s} / \mathrm{d} \\
1^{\circ}\end{array}$ & $\begin{array}{l}\text { Selasa, 24 Okt } \\
2006\end{array}$ & Istikmal \\
\hline \multirow[t]{2}{*}{$1428 \mathrm{H} / 2007 \mathrm{M}$} & Ramadhan & $\begin{array}{l}\text { Selasa, 11 Sept } \\
2007 \\
(19: 45 \text { WIB })\end{array}$ & $\begin{array}{l}-3^{\circ} \mathrm{s} / \mathrm{d} \\
-1^{\circ} 30^{\prime}\end{array}$ & $\begin{array}{l}\text { Kamis, 13 Sept } \\
2007\end{array}$ & Istikmal \\
\hline & Syawal & $\begin{array}{l}\text { Kamis, } 11 \text { Okt } \\
2007 \\
(12: 02 \text { WIB })\end{array}$ & $\begin{array}{l}0^{\circ} \mathrm{s} / \mathrm{d} \\
0^{\circ} 45^{\prime}\end{array}$ & $\begin{array}{l}\text { Sabtu, 13 Okt } \\
2007\end{array}$ & Istikmal \\
\hline \multirow[t]{2}{*}{$1429 \mathrm{H} / 2008 \mathrm{M}$} & Ramadhan & $\begin{array}{l}\text { Ahad, 31 Agt. } \\
2008 \\
(02: 59 \text { WIB) }\end{array}$ & $\begin{array}{c}4^{\circ} 17^{\prime} \mathrm{s} / \mathrm{d} \\
5^{\circ} 20^{\prime}\end{array}$ & $\begin{array}{l}\text { Senin, 1 Sept } \\
2008\end{array}$ & $\begin{array}{l}\text { RukyatGresik, } \\
\text { Jogja,Lampung, } \\
\text { Jabar }\end{array}$ \\
\hline & Syawal & $\begin{array}{l}\text { Senin, 29 Sept } \\
2008 \\
(15: 13 \mathrm{WIB})\end{array}$ & $\begin{array}{c}-2^{\circ} 21^{\prime} \mathrm{s} / \mathrm{d} \\
-1^{\circ} 18^{\prime}\end{array}$ & Rabu, 1 Okt 2008 & Istikmal \\
\hline \multirow[t]{2}{*}{$1430 \mathrm{H} / 2009 \mathrm{M}$} & Ramadhan & $\begin{array}{l}\text { Kamis, } 20 \text { Agt. } \\
2009 \\
(17: 02 \text { WIB })\end{array}$ & $\begin{array}{c}-3^{\circ} 10^{\prime} \mathrm{s} / \mathrm{d} \\
-0^{\circ} 50^{\prime}\end{array}$ & $\begin{array}{l}\text { Sabtu, } 22 \text { Agt. } \\
2009\end{array}$ & Istikmal \\
\hline & Syawal & $\begin{array}{l}\text { Sabtu, 19Sept } \\
2009 \\
(01: 44 \text { WIB })\end{array}$ & $\begin{array}{c}3^{\circ} 40^{\prime} \mathrm{s} / \mathrm{d} \\
5^{\circ} 10^{\prime}\end{array}$ & $\begin{array}{l}\text { Ahad, 20 Sept } \\
2009\end{array}$ & $\begin{array}{l}\text { Rukyat } \\
\text { dari Sukabumi, } \\
\text { Semarang, dan } \\
\text { Cakung }\end{array}$ \\
\hline
\end{tabular}


Telaah Kritis Putusan Sidang Isbat ....

\begin{tabular}{|c|c|c|c|c|c|}
\hline \multirow[t]{2}{*}{$1431 \mathrm{H} / 2010 \mathrm{M}$} & Ramadhan & $\begin{array}{l}\text { Selasa, 10 Agt. } \\
2010 \\
(10: 09 \text { WIB) }\end{array}$ & $\begin{array}{c}1^{\circ} 14^{\prime} \mathrm{s} / \mathrm{d} \\
2^{\circ} 32^{\prime}\end{array}$ & $\begin{array}{l}\text { Rabu, 11 Agt. } \\
2010\end{array}$ & $\begin{array}{l}\text { Rukyat } \\
\text { Cilincing, } \\
\text { Probolinggo, } \\
\text { Bengkulu dan } \\
\text { Condrodipo }\end{array}$ \\
\hline & Syawal & $\begin{array}{l}\text { Rabu, 8Sept } \\
2010 \\
(17: 30 \text { WIB })\end{array}$ & $\begin{array}{c}-2^{\circ} 53^{\prime} \mathrm{s} / \mathrm{d} \\
-1^{\circ} 54^{\prime}\end{array}$ & $\begin{array}{l}\text { Jum'at, 10 Sept } \\
2010\end{array}$ & Istikmal \\
\hline \multirow[t]{2}{*}{$1432 \mathrm{H} / 2011 \mathrm{M}$} & Ramadhan & $\begin{array}{l}\text { Ahad, 31 Juli } \\
2011 \\
(01: 42 \text { WIB) }\end{array}$ & $6^{\circ} 26^{\prime}$ & Senin, 1 Agt 2011 & $\begin{array}{l}\text { Rukyat } \\
\text { Bangkalan, } \\
\text { Makassar dan } \\
\text { Condrodipo }\end{array}$ \\
\hline & Syawal & $\begin{array}{l}\text { Senin, } 29 \text { Agt. } \\
2011 \\
(10: 06 \mathrm{WIB})\end{array}$ & $1^{\circ} 13^{\prime}$ & $\begin{array}{l}\text { Rabu, 31 Agt. } \\
2011\end{array}$ & Istikmal \\
\hline
\end{tabular}

Di Indonesia terdapat beberapa kriteria aliran hisab rukyat dan masingmasing aliran hisab rukyat memiliki kriteria yang berbeda. Di antara aliran dan kriteria-kriteria tersebut sebagai berikut:

\section{Muhammadiyah}

Sikap Muhammadiyah terhadap persoalan hisab rukyat, dituangkan dalam keputusan Muktamar Khususi di Pencongan Wiradesa Pekalongan pada tahun 1972. Sedangkan secara formal pemikiran hisab rukyatnya tertuang dalam himpunan putusan Majlis Tarjih Muhammadiyah. Konsep pokok yang dijadikan pedoman oleh Muhammadiyah adalah hisab wujūd al-hilāl atau hisab milād al-hilāl. Dimaksud wujūd al-hilāl di sini adalah matahari terbenam lebih dahulu daripada bulan (hilāl) walaupun hanya satu menit atau kurang. ${ }^{17}$ Penentukan tanggal 1 bulan baru berdasarkan hisab dengan tiada batasan tertentu, pokoknya asal hilal sudah wujud, maka menurut kalangan ahli hisab sudah berdasarkan hisab wujūd al-hilāl, dan dapat ditentukan hari esoknya adalah awal bulan Qamariyah.

\section{Nahdlatul Ulama}

Secara formal, pemikiran hisab rukyat NU tertuang dalam keputusan Muktamar NU XXVII di Situbondo 1984, Munas Alim Ulama di Cilacap 1987,

17Muhammad Wardan, Hisab Urfi dan Hakiki (Yogyakarta, t.p, 1987), h. 5. 
dan rapat kerja Lajnah Falakiyah NU di Pelabuhan Ratu (1992). Keputusan tersebut menekankan bahwa NU menggunakan dasar ru'yat al-hilāl bi l-fili atau istikmāl (menyempurnakan bulan menjadi 30 hari) dalam penetapan awal Ramadhan, Idul Fitri dan Idul Adha. Sedangkan kedudukan hisab hanyalah sebagai pembantu dalam melaksanakan rukyat. Penetapan awal bulan tersebut berlaku untuk umum bagi segenap lapisan kaum Muslimin di Indonesia dan dilakukan oleh Pemerintah (ithbāt al-hākim).18 Dalam kaitannya dengan garis batas pemberlakuan rukyat (mațla), prinsip pemikiran yang dipegangi NU adalah mațla' fi wilāyat al-ḥukmi.

\section{Persis}

Metode yang digunakan persis dalam penetapan awal bulan Qamariyah adalah metode hisab dengan kriteria imkān al-ru'yat. Hisab yang digunakan oleh persis termasuk hisab yang modern dan mutakhir karena menggunakan hisab ephemeris yang sudah diakui akurasinya. Dengan kriteria imkān alru'yat ini maka penetapan awal bulan qamariyah Persis, terutama Ramadhan, Syawal dan Dzulhijjah kemungkinan besar akan aman dari adanya perbedaan dengan itsbat pemerintah dan juga dengan aliran rukyat. ${ }^{19}$

\section{Hizbut Tahrir Indonesia}

Dalam hal hisab rukyat, Hizbut Tahrir Indonesia menganut prinsip rukyat global, yaitu jika salah satu penduduk negeri melihat hilal, maka penduduk seluruh negeri ikut berpuasa atau berlebaran walaupun yang lain belum melihat hilal.

Dari pemaparan berbagai kriteria aliran hisab dan rukyat di atas, dapat dikemukakan bahwa apabila hilal berada pada posisi antara $0^{\circ}-2^{\circ}$ di atas ufuk, maka diprediksi akan terjadi perbedaan. Namun bila hilal berada di bawah ufuk (negatif), maka sudah pasti menggunakan istikmāl dan diperkirakan sama. Apabila hilal sudah cukup tinggi (di atas $2^{\circ}$ ) diprediksi sudah dapat dirukyat, dan tidak ada perbedaan.

\footnotetext{
18Ahmad Izzuddin, Fiqih Hisab Rukyat, h. 110.

${ }^{19}$ Sudarmono, Skripsi dengan judul Analisis terhadap Penetapan Awal Bulan Qamariyah Menurut Persatuan Islam, Fakultas Syariah IAIN Walisongo Semarang, tahun 2008.
} 


\section{Dissenting Opinion Ormas Islam}

Penetapan awal bulan Qamariyah di Indonesia, tidak dapat lepas dari adanya dissenting opinion (perbedaan pendapat) antara anggota Ormas Islam. Beberapa Ormas yang mengikuti Sidang Itsbat, seperti Muhammadiyah, NU, Persis, Hizbut Tahrir dan sebagainya, pasti ada yang tidak sepakat dengan keputusan pemerintah. Bahkan beberapa Ormas Islam menjadikan sidang Itsbat sebagai sarana formalitas untuk "meminta izin" berlebaran lebih dahulu dari keputusan pemerintah karena perbedaan pendapat dalam penetapan awal bulan. Hal ini sebagaimana yang dilakukan oleh Muhammadiyah pada Sidang Itsbat penetapan 1 Syawal 1432 H. Dengan kondisi demikian, walaupun Sidang Itsbat selalu dilakukan untuk menyatukan pendapat berbagai ormas Islam, perbedaan akan tetap terjadi.

Salah satu faktor yang paling mendasar sebagai penyebab perbedaan adalah pedoman dan kriteria yang digunakan oleh masing-masing Ormas. Bila kriteria tersebut tetap dan tidak ada komitmen untuk persatuan, maka perbedaan akan terus terjadi. Dengan kata lain, untuk menghasilkan satu keputusan bersama, maka dibutuhkan satu kesepakatan kriteria bersama. Inilah yang saat ini terus diusahakan oleh Badan Hisab Rukyat Kementerian Agama RI. Program jangka pendek yang dilakukan BHR adalah memberi informasi kepada masyarakat tentang persoalan yang ada, sehingga apabila masih ada perbedaan, masyarakat sudah siap dan tidak menimbulkan hal-hal yang negatif, seperti meresahkan, timbul perseteruan dan mengusik ukhuwah di antara sesama Muslim. Adapun program jangka panjangnya adalah usaha penyeragaman sistem hisab, penyeragaman kriteria awal bulan, serta mengoptimalkan dan modernisasi pelaksanaan rukyat. Hingga saat ini, pemerintah telah membentuk tim perumus rancangan undang-undang hisab rukyat yang diketuai oleh Prof. Dr. Susiknan Azhari bersama empat anggota lain dari Badan Hisab Rukyat Kementerian Agama RI.

Usaha penyatuan awal bulan Qamariyah yang dilakukan pemerintah pada beberapa tahun terakhir (pasca Orde Baru) tampak lebih mengedepankan prinsip objektif ilmiah. Hal ini terbukti dengan keputusan-keputusan dalam Sidang Itsbat tetap mengikuti kriteria yang selama ini dipegangi oleh pemerintah (imkān al-ru'yat) dengan tetap menimbang data hisab dan rukyat di lapangan. Pada periode ini, keputusan Sidang Itsbat lebih bersifat 
demokratis dan tidak memihak kepentingan politik, sebagaimana yang terjadi sebelumnya pada era Orde Baru dalam penetapan awal Syawal 1412, 1413, 1414 dan $1418 \mathrm{H}^{20}$.

Sebagai contoh, dalam kalender tahun 2011, pemerintah sebenarnya telah memperkirakan 1 Syawal $1432 \mathrm{H}$ akan jatuh tanggal merah 30 dan 31 Agustus. Umumnya, tanggal merah pertama merupakan penanda tanggal 1 Syawal. Artinya, pada tanggal 30 tersebut diprediksikan sudah ada wilayah di Indonesia yang masuk tanggal 1 Syawal. Namun pada kalender tahun tersebut, 1 Syawal ditetapkan oleh pemerintah jatuh pada tanggal 31 Agustus 2011, yakni tanggal merah kedua. Pemerintah tetap konsisten dengan kriteria imkān al-ru'yat, di mana pada saat itu hilal tidak dapat dirukyat di seluruh Indonesia karena ketinggian hilal masih di bawah $2^{\circ}$. Inilah alasan pemerintah menetapkan tanggal 1 Syawal jatuh pada tanggal 31 Agustus 2011 dan merevisi penanggalan pada kalender sebelumnya.

Di samping itu, apabila terdapat perbedaan di masyarakat, konsep yang diajukan oleh pemerintah adalah tasāmuh fi al-ikhtilāf/agree in disagreement (toleransi dalam perbedaan). Bila masih belum dapat disatukan, yang dilakukan adalah saling toleransi demi kebersamaan dan kemaslahatan bersama, namun tetap berdimensi objektif ilmiah. Walaupun demikian, sampai saat ini pemerintah masih terus berupaya untuk melakukan penyatuan kriteria guna persatuan dan kebersamaan dalam melaksanakan ibadah.

Sampai saat ini memang belum ada keputusan yang dengan tegas mengharuskan atau mewajibkan rakyat Indonesia yang beragama Islam untuk mengikuti hasil sidang itsbat yang ditetapkan oleh Menteri Agama. Keputusan tersebut masih berada di tangan masyarakat dan Ormas-ormas Islam. Sehingga banyak dari mereka yang masih mengandalkan ego masing-masing dan ingin lebih menonjol daripada yang lain walaupun tidak berbasis objektif ilmiah. Inilah yang menjadi masalah bersama sampai saat ini. Setiap aliran masih mengedepankan ego masing-masing dan tidak mau mengalah untuk kemaslahatan bersama.

Namun walaupun belum ada keputusan yang mengatur kewajiban mengikuti pemerintah, Fatwa MUI No. 2 tahun 2004 tentang Penetapan Awal Rama-

20Ahmad Izzuddin, Fiqih Hisab Rukyat, h. 87-88. 
dhan, Syawal, dan Dzulhijjah, kiranya dapat menjadi inisiatif untuk membangun kebersamaan dengan mengikuti keputusan pemerintah. Fatwa tersebut berisi dua hal: Fatwa pertama, meliputi: 1) Penetapan awal Ramadhan, Syawal, dan Dzulhijjah dilakukan berdasarkan metoda rukyat dan hisab oleh Pemerintah RI cq Menteri Agama dan berlaku secara nasional; 2) Seluruh umat Islam di Indonesia wajib menaati ketetapan Pemerintah RI tentang penetapan awal Ramadhan, Syawal, dan Dzulhijjah; 3) Dalam menetapkan awal Ramadhan, Syawal, dan Dzulhijjah, Menteri Agama wajib berkonsultasi dengan Majelis Ulama Indonesia, ormas-ormas Islam dan Instansi terkait; 4) Hasil rukyat dari daerah yang memungkinkan hilal dirukyat walaupun di luar wilayah Indonesia yang mațla'-nya sama dengan Indonesia dapat dijadikan pedoman oleh Menteri Agama RI. Fatwa kedua, merupakan rekomendasi yang menyatakan: Agar Majelis Ulama Indonesia mengusahakan adanya kriteria penentuan awal Ramadhan, Syawal, Dzulhijjah untuk dijadikan pedoman oleh Menteri Agama dengan membahasnya bersama ormas-ormas Islam dan para ahli terkait.

Dengan melihat berbagai usaha yang dilakukan oleh pemerintah dan MUI di atas, dapat diambil kesimpulan bahwa pemerintah pada era sekarang ini berusaha keras untuk menyatukan penetapan awal bulan Qamariyah di Indonesia. Dasar pijakan yang digunakan pemerintah adalah objektif ilmiah, yang mempertemukan antara aliran hisab dan rukyat.

\section{Tinjauan Ushul Fikih terhadap Putusan Sidang Itsbat}

Tinjauan ushul fikih, idealisme penyelesaian hukum adalah berbasis kemaslahatan sebagaimana idealisme ajaran agama Islam. Idealisme tersebut dibingkai dalam epistemologi maqāṣid al-sharīah, yaitu teori-teori ilmu jurisprudensi Islam yang muaranya adalah demi tegaknya kemaslahatan dan terhindarkannya kerusakan (jalb al-mașālị̣ wa dar' al-mafāsid). ${ }^{21}$

Putusan sidang itsbat yang dilakukan oleh Menteri Agama untuk menetapkan awal bulan Qamariyah khususnya Ramadhan, Syawal dan Dzulhijjah memiliki tujuan untuk menjaga keabsahan dan kemantapan beribadah umat

\footnotetext{
${ }^{21}$ Abu Yasid, Aspek-aspek Penelitian Hukum, Hukum Islam - Hukum Barat (Yogyakarta: Pustaka Pelajar, 2010), h. 48-49.
} 
Islam. Demikian juga ibadah puasa Ramadhan, Idul Fitri, dan Idul Adha bukan hanya merupakan ibadah individual, melainkan ibadah memiliki nilai-nilai kesalehan sosial yang tinggi karena keberadaannya menyangkut umat Islam di seluruh dunia. Dalam istilah ushul fikih, dikategorikan sebagai maslahat al'àmah, yaitu kemaslahatan yang menyangkut kepentingan orang banyak. Untuk itu perlu didukung dengan prinsip kebersamaan dan persatuan dalam pelaksanaannya.

Dari segi kepentingan kemaslahatannya, kebersamaan dalam penetapan awal bulan Qamariyah ini termasuk dalam maslahat hạjizyah yakni kemaslahatan yang dibutuhkan dalam menyempurnakan kemaslahatan pokok sebelumnya yang berbentuk keringanan untuk mempertahankan dan memelihara kebutuhan manusia. ${ }^{22}$ Sebuah kebersamaan dalam beribadah termasuk dalam kategori memelihara kebutuhan manusia.

Atas dasar pemikiran di atas, maka untuk mencapai sebuah kebersamaan, putusan sidang itsbat pemerintah harus memenuhi kriteria kemaslahatan umat, sebagaimana kaidah ushul fikih sebagai berikut:

1. Kaidah kelima (dari 40 Kaidah Kulliyah dalam al-Ashbah wa '-Nazāïir)

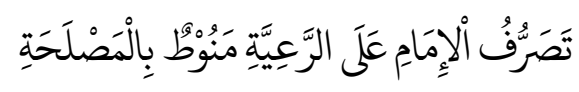

"Tindakan imam terhadap rakyatnya harus dikaitkan dengan kemaslahatan."23

Aplikasi kaidah di atas khusus dalam bidang pemerintahan yang menyangkut kebijakan pemimpin terhadap rakyatnya. Karena itu, tindakan pemimpin harus bertujuan memberi kemaslahatan manusia, baik menarik kebaikan maupun menolak kemudaratan bagi rakyatnya. Jika tindakan kebaikan pemimpin ditafsirkan buruk oleh rakyatnya, maka dalam kondisi yang demikian itu perlu memperbanyak musyawarah, karena bagaimanapun keadaannya pemerintah merupakan kristalisasi dari kehendak rakyatnya. ${ }^{24}$

\footnotetext{
22Nasrun Haroen, Ushul Fiqh 1 (Jakarta: Wacana Ilmu, 1997), h. 6. h. 83.

${ }^{23}$ Jalaluddin Abdurrahman al-Suyuthi, al-Ashbah wa I- Nazāäir (Indonesia: Syirkah Nur Asia, t.th.),

${ }^{24}$ Muhlish Usman, Kaidah-kaidah Ushuliyah dan Fiqhiyah Pedoman Dasar dalam Istinbath Hukum Islam (Jakarta: Raja Grafindo Persada, 1997), h. 150.
}

128 || Volume 25, Nomor 1, April 2015

AL-AHKAM - ISSN 0854-4603 
Kemaslahatan yang ditempuh pemimpin harus mempertimbangkan kemaslahatan yang lebih universal mencakup totalitas masyarakat, tidak mementingkan kemaslahatan golongan atau individu. ${ }^{25}$ Demikian halnya dalam penetapan awal bulan Qamariyah, pemimpin (Menteri Agama dan Badan Hisab Rukyat) tidak boleh mementingkan kemaslahatan golongan atau individu saja, namun harus mengedepankan kemaslahatan yang lebih universal.

2. Kaidah ketigapuluh tiga (dari 68 kaidah tambahan dalam al-Majallat al-Aḥkām al-'Adliyyah)

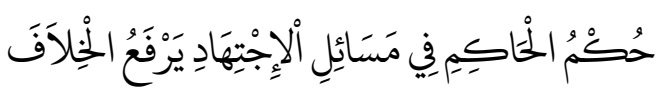

"Keputusan hakim dalam ijtihad dapat menghilangkan persengketaan." 26

Aplikasi kaidah ini adalah apabila dalam suatu kasus beberapa hakim menetapkan hukum yang berbeda-beda, kemudian tim tersebut mengambil keputusan yang dianggap lebih kuat, maka pihak-pihak lain tidak boleh mengingkari keputusan hakim tersebut. ${ }^{27}$

Dalam hal hisab rukyat, kaidah ini dapat diaplikasikan dalam hal penetapan awal bulan Qamariyah. Ketika dalam sebuah kasus terdapat beberapa aliran atau kelompok hisab rukyat yang berbeda-beda dalam memutuskan, maka tim yang terbentuk dalam Badan Hisab Rukyat akan mengambil keputusan yang dianggap lebih kuat (di antaranya melalui sidang itsbat yang diputuskan oleh Menteri Agama), di mana keputusan tersebut didasarkan pada kajian yang objektif ilmiah dan merupakan jembatan yang menyatukan keputusan aliran yang berbeda tersebut, maka aliran-aliran tersebut tidak boleh mengingkari keputusan yang telah dibuat. Mereka harus mengikuti hasil putusan yang telah ditetapkan oleh Menteri Agama dalam sidang itsbat. Hal ini sesuai dengan kaidah di atas, bahwa keputusan hakim (Menteri Agama) dalam sebuah ijtihad dapat menghilangkan persengketaan antara berbagai aliran hisab rukyat di Indonesia.

25Ibid, h. 151.

${ }^{26}$ Asjmuni A. Rahman, Qaidah-Qaidah Fiqh (Jakarta: Bulan Bintang, 1976), h. 70.

27Muhlish Usman, Kaidah-Kaidah Ushuliyah dan Fiqhiyah, h. 191-192. 
Siti Tatmainul Qulub

3. Kaidah ketigapuluh empat (dari 68 kaidah tambahan dalam al-Majallat alAhkām al-'Adliyyah)

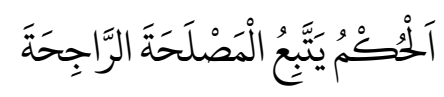

"Hukum itu mengikuti kemaslahatan yang paling kuat/banyak." 28

Penetapan awal bulan Qamariyah 1 Syawal 1432 H, terdapat perbedaan pendapat antara NU dan Muhammadiyah. NU dengan ru'yatul hilāl menetapkan tanggal 1 Syawal jatuh pada tanggal 31 Agustus 2011, sedangkan Muhammadiyah dengan wujūd al-hilāl menetapkan jatuh pada tanggal 30 Agustus 2011. Berdasarkan dalil yang paling kuat yakni data hisab dan laporan rukyat dari berbagai titik di seluruh Indonesia, sidang itsbat memutuskan bahwa tanggal 1 Syawal $1432 \mathrm{H}$ jatuh pada tanggal 31 Agustus 2011, karena pada tanggal 29 Ramadhan/29 Agustus hilal tidak dapat dirukyat dan ketinggian hilal pada saat itu belum memenuhi kriteria hilal mungkin dapat dirukyat (imkān al-ru'yat).

Putusan tersebut mempertimbangkan kemaslahatan untuk sebuah kesepakatan kebersamaan dalam beridul fitri dan didasarkan pada kajian yang objektif ilmiah. Karena bila tidak bersatu tentu akan menimbulkan kekacauan dan mengganggu ukhuwah islamiyah umat Islam. Oleh karena itu, seharusnya semua elemen masyarakat dapat mengambil dan mengikuti keputusan yang memberikan kemaslahatan yang paling kuat/banyak yaitu keputusan pemerintah.

Bila setiap aliran memberikan keputusan masing-masing kepada jama'ah, tentu kemaslahatan yang ditimbulkan lebih sedikit karena hanya satu golongan dibanding bila bersama-sama. Bila mengikuti pemerintah, maka akan terbentuk sebuah kebersamaan dalam beribadah dan kemaslahatan yang ditimbulkan akan lebih besar.

4. Kaidah keenampuluh tujuh (dari 68 kaidah tambahan dalam al-Majallat alAhkām al-'Adliyyah)

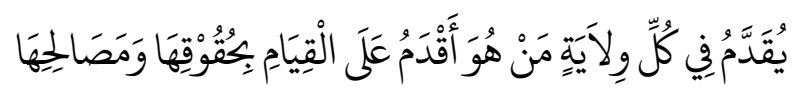

${ }^{28}$ Asjmuni A. Rahman, Qaidah-Qaidah Fiqh, h. 71.

130 || Volume 25, Nomor 1, April 2015

AL-AHKAM — ISSN 0854-4603 
"Orang-orang yang lebih berani menegakkan hak-hak dan kemaslahatankemaslahatan harus didahulukan pada setiap kekuasaan." 29

Karena itu penguasa negara harus diberikan pada orang yang mengerti politik negara, dalam peperangan komandannya diserahkan pada yang mengerti strategi perang, dalam peradilan kekuasaannya diberikan pada orang yang mengerti hukum dan sebagainya. ${ }^{30}$ Begitu pula dalam penentuan awal bulan Qamariyah diberikan pula pada tim yang terdiri dari ahli falak, ahli astronomi, ahli fikih, dan sebagainya agar keputusannya dapat mencakup semua golongan dan memberikan kemaslahatan bersama.

\section{Kesimpulan}

Sidang itsbat penetapan awal bulan Ramadhan, Syawal, dan Dzulhijjah adalah sebuah ikhtiar yang wajib dilakukan oleh pemerintah (selaku imām sekaligus hākim) untuk menyelesaikan perbedaan pendapat yang sering terjadi di antara Ormas di Indonesia. Dalam perspektif ushul fikih, sidang itsbat dilaksanakan untuk mengupayakan terwujudnya kemaslahatan bersama (maslaḥat 'àmmah) yang menjadi esensi dari maqāșid al-sharīah (tujuan syari'ah). Pelaksanaan sidang itsbat merupakan salah satu contoh bentuk maslahat hājiyyah yang dibutuhkan demi menyempurnakan ibadah puasa Ramadhan, Idul Fitri, dan Idul Adha. Yakni kemaslahatan yang dibutuhkan dalam menyempurnakan kemaslahatan pokok sebelumnya yang berbentuk keringanan untuk mempertahankan dan memelihara kebutuhan manusia. Nilai maslahat tersebut adalah sebuah kebutuhan untuk bersama-sama dalam pelaksanaan ibadah di bulan-bulan Qamariyah yang dimuliakan tersebut.[a]

\section{DAFTAR PUSTAKA}

Ali, Hamdany, Himpunan Keputusan Menteri Agama, cet. I, Jakarta: Lembaga Lektur Keagamaan, 1972.

Azhari, Susiknan, Ensiklopedi Hisab Rukyat, Cet. II, Yogyakarta: Pustaka Pelajar, 2008.

\footnotetext{
${ }^{29}$ Asjmuni A. Rahman, Qaidah-Qaidah Fiqh, h. 139.

30Muhlish Usman, Kaidah-Kaidah Ushuliyah dan Fiqhiyah, h. 205.
} 
Siti Tatmainul Qulub

Azhari, Susiknan, Sa'adoeddin Djambek (1911 - 1977) dalam Sejarah Pemikiran Hisab di Indonesia, Yogyakarta: IAIN Yogyakarta, 1999.

Direktorat Jenderal Bimbingan Masyarakat Islam Kementerian Agama RI, Almanak Hisab Rukyat, 2010.

Direktorat Jenderal Bimbingan Masyarakat Islam Kementerian Agama Republik Indonesia tahun 2010, Almanak Hisab Rukyat, 2010.

Fatah, Adib Bisri dan Munawwir A., Kamus al-Bisri, Surabaya: Pustaka Progressif, 1999.

Haroen, Nasrun, Ushul Fiqh 1, Jakarta: Wacana Ilmu, 1997.

Izzuddin, Ahmad, Fiqih Hisab Rukyat, Jakarta: Erlangga, 2007.

Kementerian Agama RI, "Keputusan Menteri Agama Republik Indonesia dalam Penetapan 1 Ramadhan, Syawal dan Dzulhijjah 1381 H-1432 H/1962 M$2011 M^{\prime \prime}, 2011$.

Keputusan Menteri Agama Republik Indonesia tentang Penetapan Tanggal 1 Ramadhan, dan 1 Syawal.

Keputusan Temu Kerja Evaluasi Hisab Rukyat Tahun 2007.

Khazin, Muhyiddin, Makalah Teknik Pelaksanaan Rukyatul Hilal dan Sidang Itsbat, Subdit Pembinaan Syari'ah dan Hisab Rukyat Departemen Agama RI tahun 2008.

Materi Sidang Anggota Badan Hisab Rukyat Departemen Agama RI tahun 2007.

Nasution, Harun, Ensiklopedi Islam Indonesia, cet. I, Jakarta: Djambatan, 1992.

Rahman, Asjmuni A., Qaidah-Qaidah Fiqh, Jakarta: Bulan Bintang, 1976.

Sudarmono, Analisis terhadap Penetapan Awal Bulan Qamariyah Menurut Persatuan Islam, skripsi, Fakultas Syariah IAIN Walisongo Semarang, tahun 2008.

al-Suyuthi, Jalaluddin Abdurrahman, al-Ashbah wa I-Nazā̄ir, Indonesia: Syirkah Nur Asia, t.th.

Usman, Muhlish, Kaidah-kaidah Ushuliyah dan Fiqhiyah Pedoman Dasar dalam Istinbath Hukum Islam, Jakarta: Raja Grafindo Persada, 1997.

Wardan, Muhammad, Hisab 'Urfi dan Hakiki, Yogyakarta, t.p, 1987.

Yasid, Abu, Aspek-aspek Penelitian Hukum, Hukum Islam - Hukum Barat, Yogyakarta: Pustaka Pelajar, 2010.

132 || Volume 25, Nomor 1, April 2015

AL-AHKAM — ISSN 0854-4603 